\title{
Ventilation Transport Trade Study for Future Space Suit Life Support Systems
}

Robert Kempf, Matthew Vogel (Jacobs Engineering)

Heather L. Paul (NASA Johnson Space Center)

\section{ABSTRACT}

A new and advanced portable life support system (PLSS) for space suit surface exploration will require a durable, compact, and energy efficient system to transport the ventilation stream through the space suit. Current space suits used by NASA circulate the ventilation stream via a ball-bearing supported centrifugal fan. As NASA enters the design phase for the next generation PLSS, it is necessary to evaluate available technologies to determine what improvements can be made in mass, volume, power, and reliability for a ventilation transport system. Several air movement devices already designed for commercial, military, and space applications are optimized in these areas and could be adapted for EVA use. This paper summarizes the efforts to identify and compare the latest fan and bearing technologies to determine candidates for the next generation PLSS.

\section{INTRODUCTION}

An investigation of state-of-the-art gas transport device technologies was performed in support of the Constellation Space Suit Element (CSSE) advanced portable life support system (PLSS) preliminary design work being performed at National Aeronautics and Space Administration (NASA) Johnson Space Center (JSC). The primary objective of this investigation was to identify top gas transport candidates for potential use in the CSSE PLSS ventilation loop. Commercial, industrial, military, and aerospace markets as well as NASA sponsored programs were surveyed. Gas transport devices considered included axial and centrifugal fans and piston, rotary vane, and diaphragm positive displacement pumps. The extensive survey produced an initial list of candidates that was then refined to include only those that had potential to meet the CSSE PLSS flow requirements. These remaining candidates were evaluated and scored in four categories including required input power, mass, volume, and fan speed scaling required to meet flow requirements. Scores were totaled to identify top ranking candidates.

A key motivation of this investigation was the recognition that prior technical knowledge had not been completely captured. The Apollo and Space Shuttle Extravehicular Mobility Units (EMU) used centrifugal fans whereas an International Space Station (ISS) EMU prototype fan [1] was a gas bearing axial fan. The advantages of using a gas bearing axial fan in an EMU are not readily apparent and no documentation supporting this design selection has been found. A cursory look at typical aerodynamic efficiencies and the desire to minimize electrical power consumption also motivated this investigation. The ISS EMU prototype fan design point aerodynamic power and electrical power consumption was respectively $3.5 \mathrm{~W}$ (6 cfm flow, 5 inches $\mathrm{H}_{2} \mathrm{O}$ delta pressure) and $23.6 \mathrm{~W}$, yielding an efficiency of $15 \%$. The assumption of a CSSE PLSS gas transport device with the same efficiency results in a gas movement device consuming $8.0 \mathrm{~W}$ of electrical power to produce $1.2 \mathrm{~W}$ of aerodynamic power at the current CSSE PLSS design conditions of $4.7 \mathrm{cfm}$ flow and a delta pressure of 2.2 inches of $\mathrm{H}_{2} \mathrm{O}$. This investigation is the first step to ascertaining the feasibility of significantly reducing gas transport device electrical power consumption. 


\section{GAS FLOW DEVICES AND TECHNOLOGIES}

Fans and pumps are the two principal types of gas movement devices that were investigated for PLSS applications. Both types of devices can be further divided into several subcategories based on design features, however this section will focus only on those that were found to be capable of efficiently meeting PLSS performance requirements.

\subsection{FANS}

\subsubsection{FAN DESIGNS}

Fans are machines that produce air flow by means of delta pressures created by a rotating impeller [2,3]. These devices are optimized for moving large volumes of air through relatively low delta pressures when compared to pumps, although the flow and pressure capacity of a fan are largely determined by the type of impeller used. Fans can be categorized as either axial or centrifugal flow types based on the path of the air flow through the fan, as shown in Figure 1.

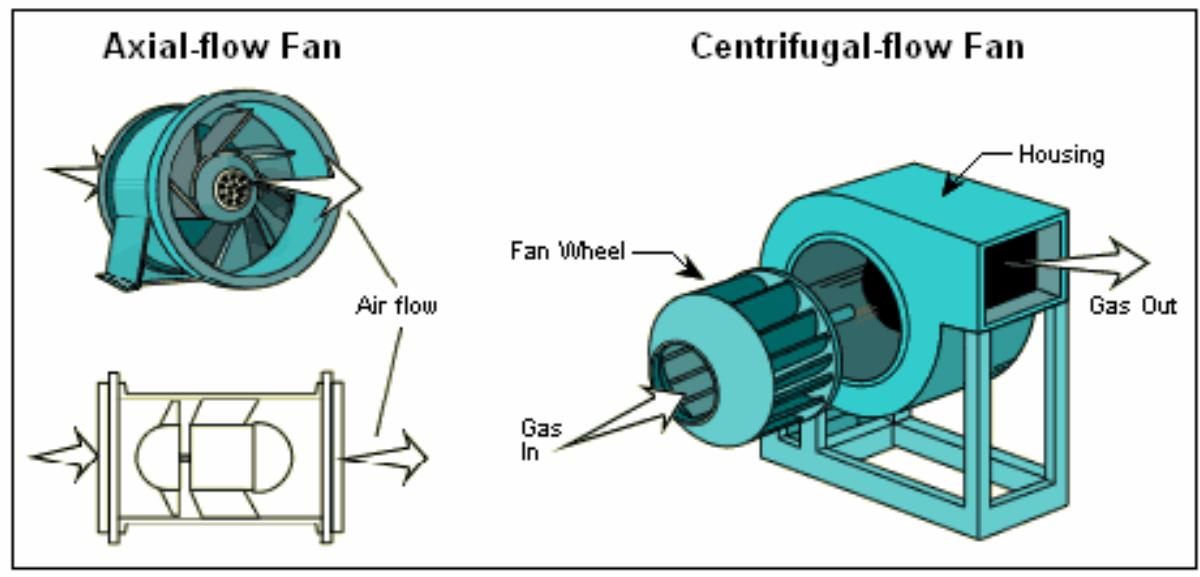

Figure 1. Comparison of Axial and Centrifugal-flow Fan Designs [4]

In axial-flow fans the direction of the air flow remains the same between the fan inlet and outlet. Examples of axial-flow fans would be ordinary ceiling fans and aircraft propellers. Axial fans are usually specialized for applications requiring high flow rates through little or no delta pressure. Centrifugal-flow fans expel fluid at a $90^{\circ}$ angle from the fan inlet. Impellers in these types of fans use the centrifugal force generated by their rotation to accelerate fluid outward from the center. Centrifugal fans are capable of creating greater delta pressures than most axial fan types.

\subsubsection{FAN PERFORMANCE}

A fan's aerodynamic performance is best characterized by its volumetric flow rate and delta pressure, i.e. the difference in pressure between the fan inlet and outlet. At a constant fan speed, these two parameters are functions of each other. This relationship is usually described graphically by using what is called a fan performance curve. Typically, a performance curve is obtained by running a fan at a constant voltage through various system hydraulic impedances, or resistances to flow. These range from no impedance, where the fan is free flowing and all energy is converted into velocity, to full impedance, where flow resistance is at a maximum and all energy is converted into pressure. 
Performance curves can be particularly useful when paired with a system curve. Any given system with a constant impedance can be described graphically by using a system curve. Like a performance curve, the system curve relates delta pressure and volumetric flow. Delta pressure increases as volumetric flow is increased through a fixed system. When a fan is used to create flow through a system, the operating point, i.e. the flow and pressure that can be expected, is determined by the intersection of the fan's performance curve and the system's characteristic curve. Therefore, a fan at a constant speed will deliver only one specific flow and pressure combination for a given system. A generalized example of this graphical method is shown in Figure 2.

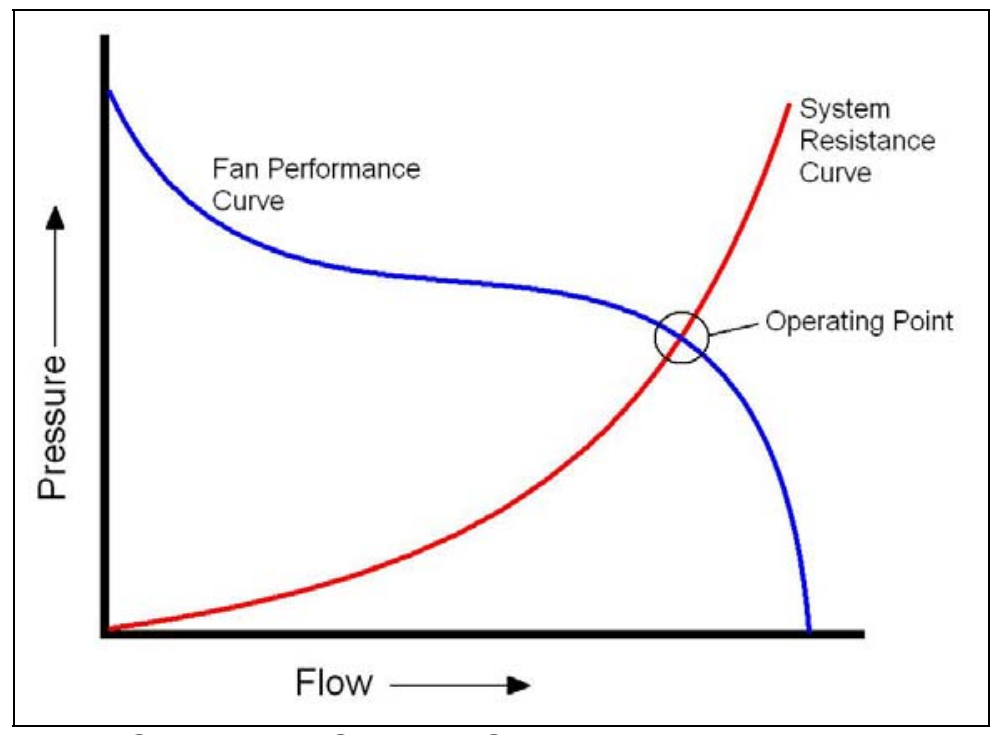

Figure 2. Fan Performance Curve and System Curve Example

\subsection{POSITIVE DISPLACEMENT PUMPS}

\subsubsection{POSITIVE DISPLACEMENT PUMP DESIGNS}

Positive displacement pumps are machines designed to flow a fixed volume of fluid through potentially large delta pressures [1,5]. These pumps use mechanical means to trap and move a fixed volumes of fluid during each cycle through reciprocating or rotary actions. The flow capacity of a positive displacement pump is limited by its chamber volume and speed. The three general types of positive displacement pumps relevant to this study are diaphragm, piston, and rotary vane pumps, whose designs are shown in Figure 3. 


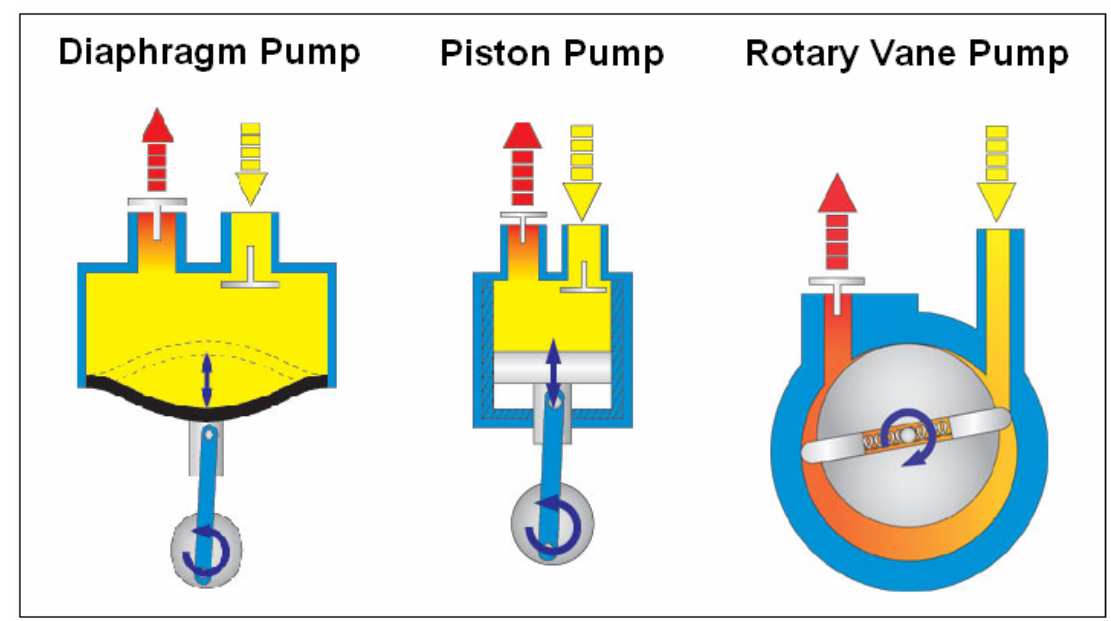

Figure 3. Schematic of Diaphragm, Piston, and Rotary Vane Pump Operation [4]

Diaphragm pumps are a type of reciprocating pump that uses a flexible diaphragm head to trap and release fluid as the diaphragm expands and contracts. Multiple heads can be used to increase a diaphragm pump's capacity. Check valves limit the inflow and outflow from the diaphragm and the design eliminates the need for seals between moving parts.

Piston pumps are another type of reciprocating pump where the volume of transported fluid is regulated by the motion of a tightly fitted shaft sliding within a fixed chamber. Seals are usually required between the shaft and chamber to prevent fluid leakage. These seals may be a limiting factor in the pressure capacity of the pump.

Rotary vane pumps consist of sliding vanes, or blades, situated inside a slotted rotor within the pump housing. As the rotor spins, centrifugal forces push the vanes against the housing wall creating pockets that trap and discharge fluid as they spin past the fluid inlet and outlet. Although vane pumps are rotary in operation, they do not use centrifugal forces to move and accelerate the fluid.

\subsubsection{POSITIVE DISPLACEMENT PUMP PERFORMANCE}

Unlike fans, positive displacement pumps create pressure independently from the flow rate. There is no relation between these two performance characteristics as there is in fans. Theoretically, given a constant speed, a positive displacement pump will produce a constant flow no matter the delta pressure. A pump will produce any pressure required to pump a given capacity. Realistically, the pressure capabilities of a pump are limited by the motor power and fluid slippage within the device. In real operations, the flow will begin to decrease as the delta pressure rises, but this flow decay is completely device specific and due to the pump's design.

\subsection{FOIL GAS BEARINGS}

Recommendations by previous PLSS design teams to incorporate foil gas bearings in future PLSS ventilation fan designs made it appropriate to research their operational principals and capabilities as part of this study. Due to the specialized nature and limited current applications of this type of bearing, an overview of foil gas bearing technology is included for reference.

Foil gas bearings, often called air bearings, are self-acting hydrodynamic bearings that use gas or air as the lubricant $[6,7,8]$. The shaft is surrounded by stationary, but flexible, metal foils 
encased in a solid housing. The shaft stays in contact with these foils while stationary, and a small preload exists between the shaft and foils. Once spinning, the hydrodynamic pressure created by the shaft causes the foils to expand outward, leaving the shaft supported by a thin layer of pressurized gas. The shaft is completely airborne during nominal operation and is only in contact with the foils briefly during startup and shutdown when the shaft speed is not high enough to create the required dynamic pressure for a sufficient fluid film.

Foil gas bearings provide several advantages over traditional rolling element bearings. Because there are fewer parts and minimal wear related to the bearing assembly, the expected lifetime of a foil gas bearing is much longer compared to rolling element bearings. The bearing and shaft are protected from wear by the gas film during normal operation, and the brief periods of contact that occur during startup and shutdown are not enough to produce significant wear. Supporting the shaft on a gas film has additional benefits, including a nearly unlimited shaft speed, no need for any additional lubrication, and the ability to operate at temperatures much higher and lower than where traditional oil lubricants would fail. Foil gas bearings are also unaffected by heavy airborne contaminants such as sand or dust.

Foil bearing technology has been in development since the 1960's. Some key design features, mainly affecting the load capacity of the bearings, separate foil gas bearings into the three distinct generations shown in Figure 4.

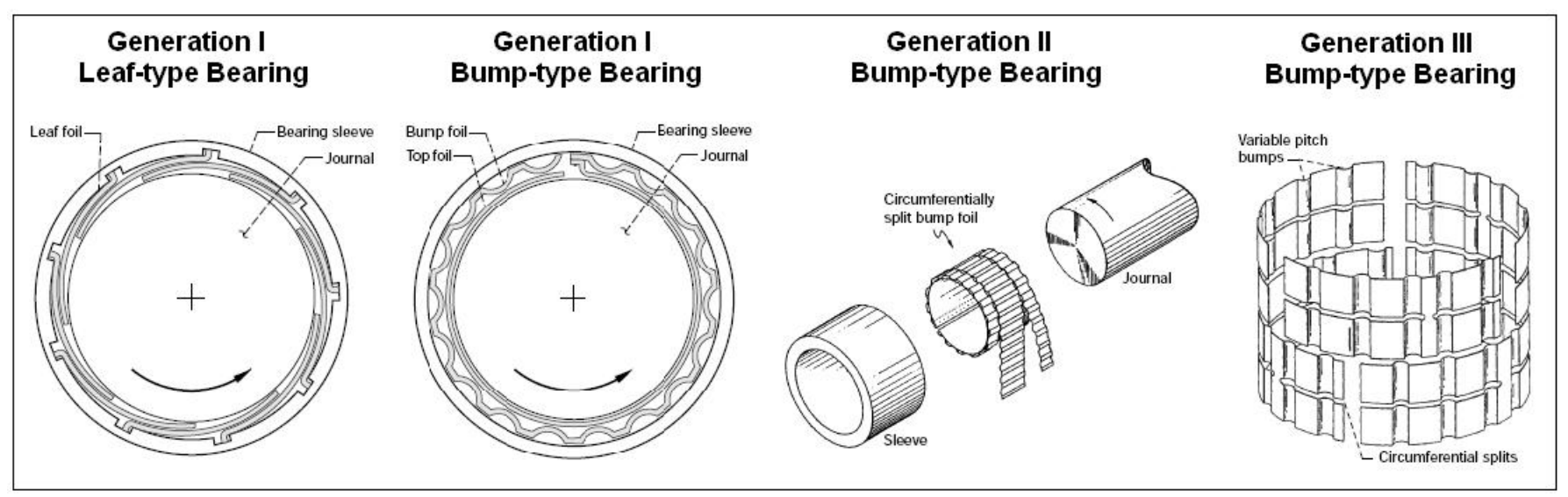

Figure 4. Foil Gas Journal Bearing Schematics [9]

First generation foil journal bearings consist of early "leaf-type" or "bump-type" designs of the 1960's and 1970's. Leaf-type, or multipad, foil bearings use a series of overlapping metal foils to create an iris around the shaft that expands after sufficient hydrodynamic pressure forms. First generation bump-type foil bearings consist of two main elements; the top foil and bump foil. The top foil is a single, smooth metal piece that wraps around and encases the shaft. The bump foil of first generation bearings, a single metal piece with parallel and uniform ridges, is situated between the top foil and bearing casing and acts as a spring to correct any shaft eccentricity. Second generation foil bearings of the 1970's and 1980's use the same basic concepts as first generation bearings, but introduce variations to the support characteristics in either the axial or circumferential directions by using multiple bump foils with differing bump patterns or characteristics. Third generation foil bearings developed since the 1990's vary the support characteristics in both the axial and circumferential directions. 
Foil gas bearings have been most successfully utilized in air cycle machines on commercial and military aircraft, starting with the DC-10 in 1969. Air cycle machines bleed air from the turbines to distribute it throughout the cabin and are the heart of any aircraft environmental control system. Foil bearings have become the standard bearing used in this application since their introduction in 1969. Foil bearings used in this application have shown a mean time between failure in excess of 100,000 hours. Recent advancements in bearing load capacity have allowed for the possibility of using foil bearing technology in larger applications such as turbine engines.

\section{FLOW REQUIREMENTS AND BASELINES}

\subsection{FLOW REQUIREMENTS}

Due to the preliminary nature of this study, devices were evaluated only with respect to flow requirements to ensure that a larger collection of candidates could be considered and compared. For convenience, flow requirements were derived by assuming that the CSSE ventilation loop will have the same characteristics as the EMU ventilation loop. Along with equal pressure drop performance, this assumption requires the gas transport device inlet volumetric flow to be 1.18 times of that needed at the helmet. The 1.18 factor accounts for varying gas densities from the fan inlet to the helmet inlet. Currently, the CSSE helmet volumetric flow rate design point is 4 cubic feet per minute (cfm) for the hemispherical helmet. [10] Applying the 1.18 factor yields a gas transport device inlet flow requirement of $4.7 \mathrm{cfm}$. To account for potential future changes in helmet flow rate requirements, gas transport device candidates were measured against a second helmet flow rate of $5 \mathrm{cfm}$, which results in a gas transport device inlet flow rate requirement of $5.9 \mathrm{cfm}$.

Figure 5 presents EMU ventilation loop pressure drop calculations from which the CSSE gas transport device delta pressures were derived. Candidate gas transport devices were evaluated against the 14.7 psia EMU pressure drops as opposed to the 4.3 psia pressure drops because commercial-off-the-shelf manufacturers usually test and report only for 14.7 psia device operations. Table 1 summarizes flow requirements for 4.3 and 14.7 psia operations showing that the device must generate delta pressures of 6.3 and 9.5 in. $\mathrm{H}_{2} \mathrm{O}$ for 4.7 and $5.9 \mathrm{cfm}$ device inlet volumetric flows, respectively, given a 14.7 psia atmospheric pressure.

Table 1. PLSS Ventilation Flow Requirements

\begin{tabular}{|c|c|c|c|}
\hline $\begin{array}{c}\text { Helmet Volumetric Flow } \\
\text { Rate }\end{array}$ & Absolute Pressure & $\begin{array}{c}\text { Gas Transport Device } \\
\text { Inlet Volumetric Flow Rate }\end{array}$ & $\begin{array}{c}\text { Device Delta } \\
\text { Pressure }\end{array}$ \\
\hline $4 \mathrm{cfm}$ & $4.3 \mathrm{psia}$ & $4.7 \mathrm{cfm}$ & $2.2 \mathrm{in} . \mathrm{H}_{2} \mathrm{O}$ \\
\hline $4 \mathrm{cfm}$ & $14.7 \mathrm{psia}$ & $4.7 \mathrm{cfm}$ & $6.3 \mathrm{in} . \mathrm{H}_{2} \mathrm{O}$ \\
\hline $5 \mathrm{cfm}$ & $4.3 \mathrm{psia}$ & $5.9 \mathrm{cfm}$ & $3.3 \mathrm{in} . \mathrm{H}_{2} \mathrm{O}$ \\
\hline $5 \mathrm{cfm}$ & $14.7 \mathrm{psia}$ & $5.9 \mathrm{cfm}$ & $9.5 \mathrm{in} . \mathrm{H}_{2} \mathrm{O}$ \\
\hline
\end{tabular}


EMU Vent Loop Total Pressure Drop

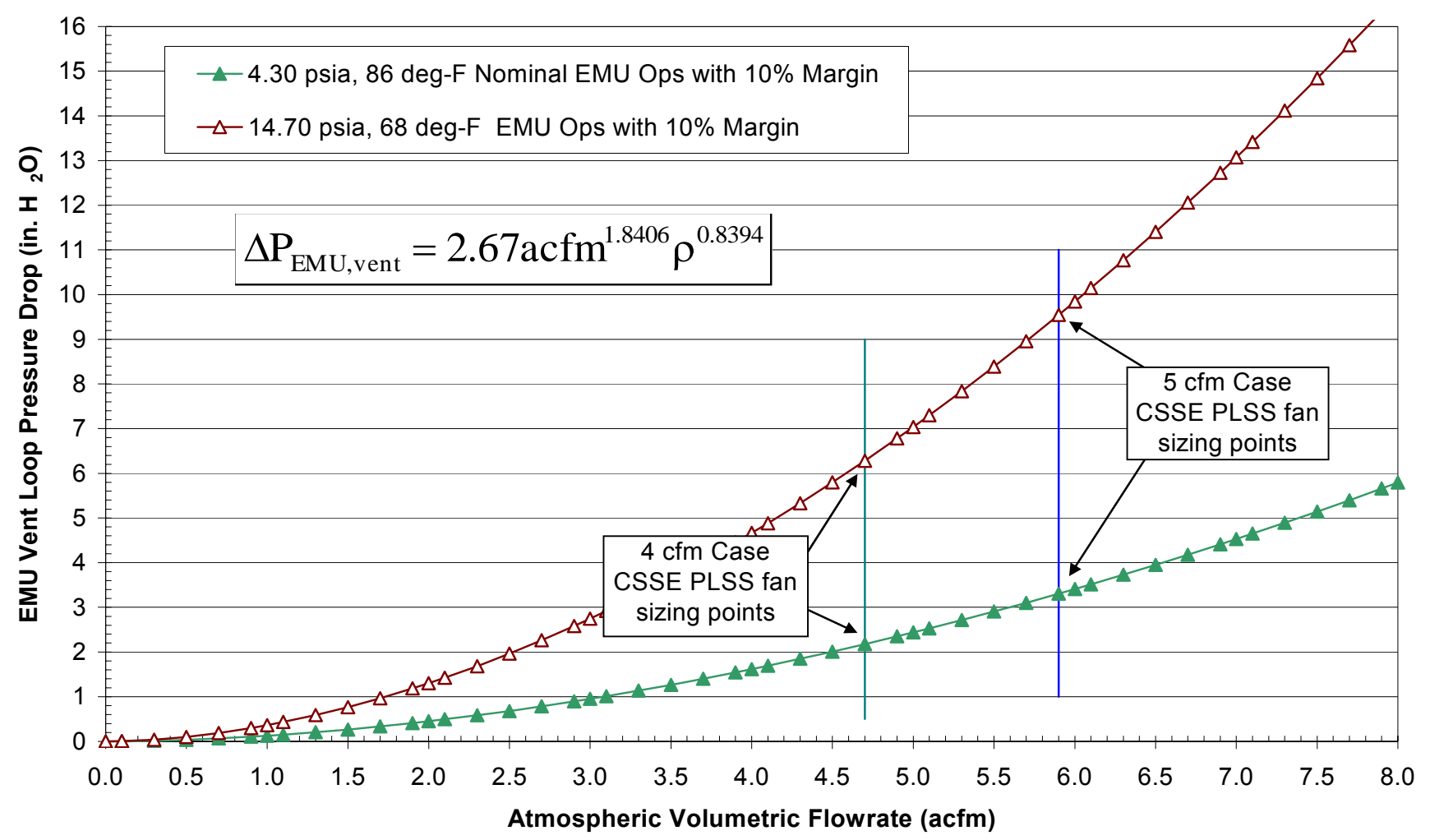

Figure 5. Space Shuttle EMU Ventilation Loop Pressure Drop

\subsection{BASELINES}

There are devices specifically developed for PLSS applications that were used as baselines in this study. These fans have proven capable of meeting other PLSS ventilation requirements, and it was a goal of this study to find devices comparable to these designs that may meet or exceed their performance.

\subsubsection{CURRENT EMU VENTILATION FAN}

The ventilation fan used in current NASA EMUs, designed by Hamilton Sundstrand, is part of a single assembly that also includes the suit water pump and water separator [11]. All components of the assembly, pictured in Figure 6 below, are powered by a single brushless DC motor. This ventilation device is a ball bearing supported centrifugal fan. It is designed to flow $6.4 \mathrm{cfm}$ with a delta pressure of 3.6 in. $\mathrm{H}_{2} \mathrm{O}$ at 3.92 psia in Extravehicular Activity (EVA) mode. The motor accepts a $15.5 \mathrm{~V} \mathrm{DC}$ voltage to run the fan at a nominal speed of $19,555 \mathrm{rpm}$. The assembly was subjected to extensive life cycle, thermal, shock load, and oxygen compatibility testing. The entire assembly weighs $3.5 \mathrm{lbs}$ and draws $34.7 \mathrm{~W}$ of power, although it is not known how much weight or power draw can be attributed to the fan alone. 


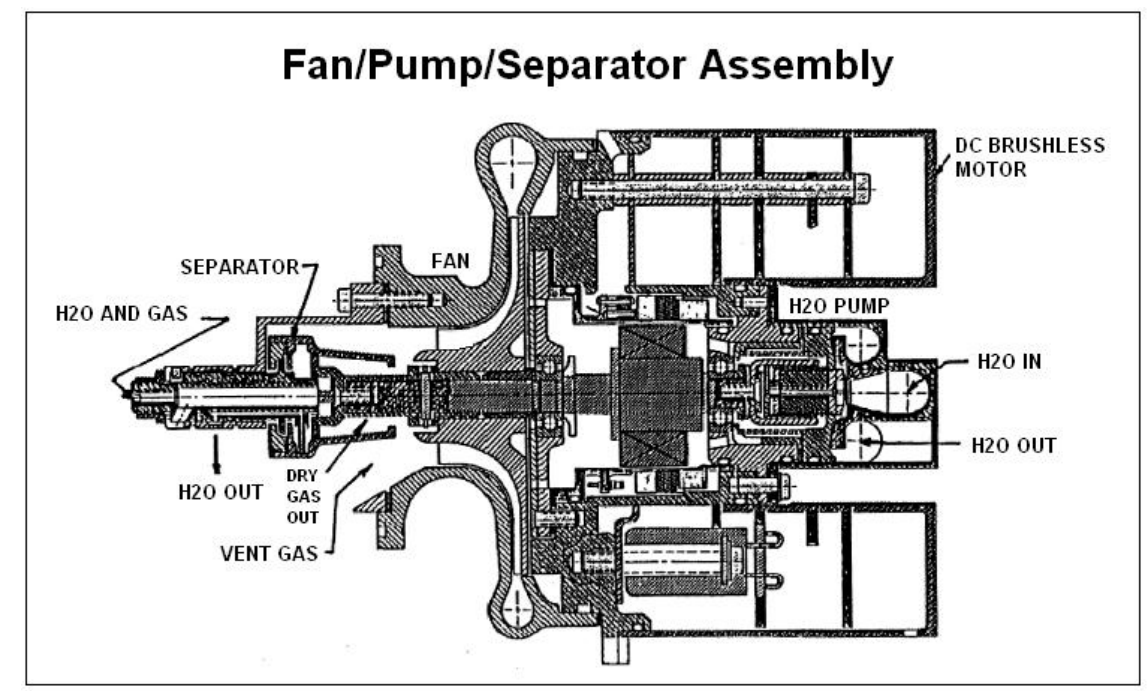

Figure 6. EMU Fan/Pump/Separator Assembly Design [9]

\subsubsection{PROTOTYPE EMU GAS BEARING FAN}

In 1992 Allied-Signal, AiResearch Los Angeles Division, completed the design, development, fabrication, and preliminary testing of a high-speed axial gas bearing fan in support of a Lockheed Engineering and Sciences Company subcontract. [1] The fan was designed to meet the specifications of a preprototype PLSS whose goal was to emphasize life support technologies that are low volume, low weight, highly sustainable, and beneficial to future PLSS designs. The fan, shown in Figure 7, weighs under $2 \mathrm{lbs}$ and measures 7 inches long with a volume under 19 cubic inches.

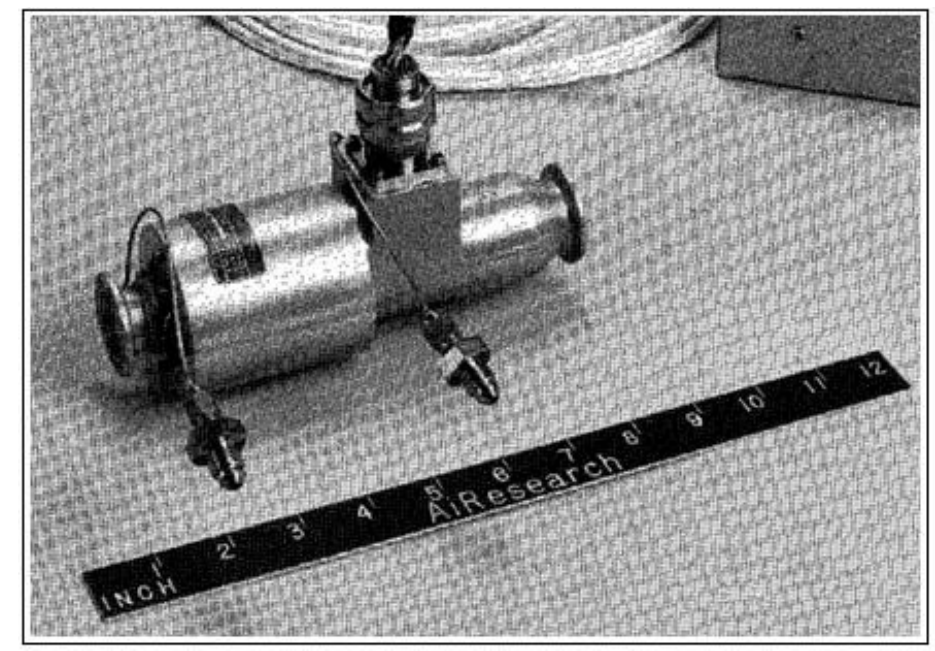

Figure 7. Prototype Gas Bearing Ventilation Fan [11]

The ventilation fan was designed to generate a 5 in. $\mathrm{H}_{2} \mathrm{O}$ delta pressure at $6 \mathrm{cfm}$ flow in an 8.3 psia atmospheric pressure. It utilizes foil gas bearings coated with a durable, high-temperature, low friction coating to support a high-speed axial impeller rotating at $166,000 \mathrm{rpm}$. The shaft is driven by a brushless DC permanent magnet drive motor and a $28 \mathrm{~V} \mathrm{DC}$ high-speed controller. The fan was built with materials that satisfied NASA oxygen compatibility specifications at the time. Figure 8 shows the detailed fan and bearing design. 


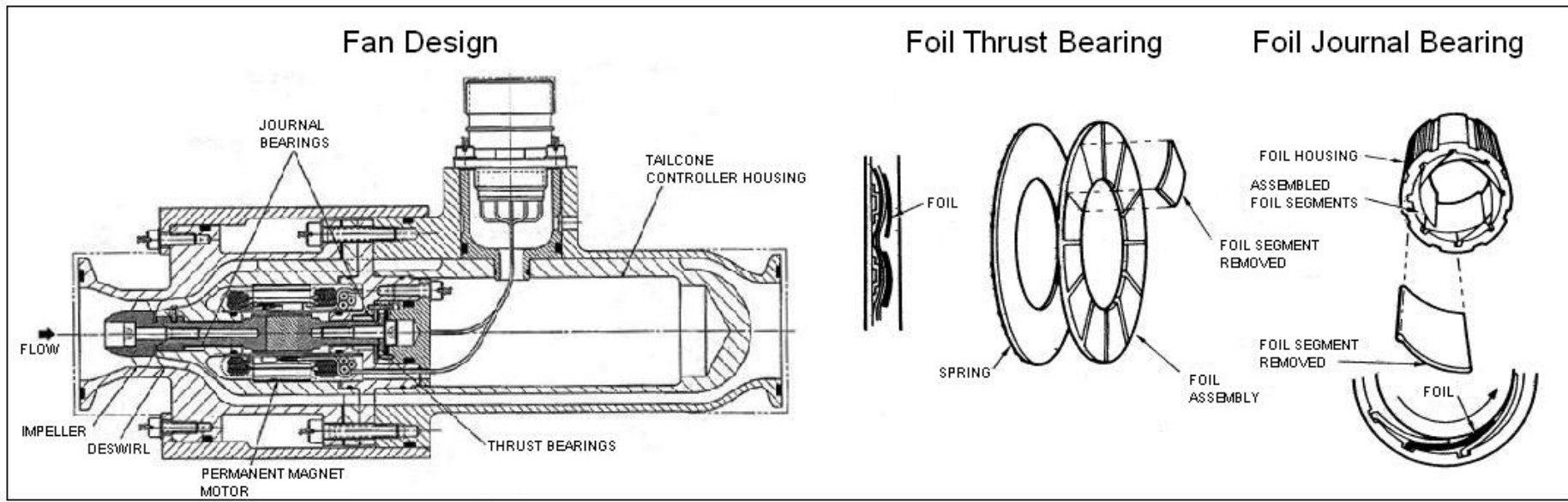

Figure 8. Prototype Ventilation Fan and Bearing Design [12]

The fan was tested in a closed loop test stand where performance was measured at inlet pressures ranging from 6 to $23 \mathrm{psi}$. At the design pressure of 8.3 psia, flows during testing ranged from $3.5 \mathrm{cfm}$ at the minimum shaft speed $90,000 \mathrm{rpm}$, to $8 \mathrm{cfm}$ at the maximum shaft speed of $215,000 \mathrm{rpm}$, with corresponding delta pressures ranging from 2.1 to 8 in. $\mathrm{H}_{2} \mathrm{O}$. The total power draw at the design point was $23.6 \mathrm{~W}$, although up to $7.2 \mathrm{~W}$ of the total power was attributed to controller losses. AiResearch points out that improvements in power consumption, weight, and performance can be made to this fan through changes in aerodynamic efficiency and manufacturing materials, which are outlined in a final report.

\section{MARKET SURVEY AND CANDIDATES}

A wide scope of markets and industries were surveyed to locate ventilation transport candidates for this study. The final collection of candidates can be organized into three general categories of devices: commercial fans, commercial pumps, and NASA developed fans. Most commercial fans and pumps were selected based on their compactness and ability to meet the CSS PLSS flow requirements. Small commercial gas bearing fans were difficult to find as the market currently appears to be limited to small fuel cells. Data on the few candidates found was lacking, partly because the fans themselves are in early development stages and partly because manufacturers were reluctant to share data. However, these candidates were still noted for future reference since the fan developments in this niche market are promising and should be monitored. NASA fans selected for this study were ones known to utilize gas bearings, as well as fans used for the purpose of ventilation. All information pertaining to their performance and design was obtained from their respective manufacturers, except where otherwise noted.

\subsection{COMMERCIAL FANS}

A total of 17 commercial fans were selected for consideration in this study. All are centrifugal fans, as most axial fans are not capable of producing the required delta pressures at the required flow rate of $4.7 \mathrm{cfm}$. The Ametek, Delta, and Micronel fans are powered by brushless direct current (BLDC) motors while the type of motor used in the Honeywell fan is not known. Popular applications for these fans include electronics and equipment cooling, medical respiration, fuel cell gas injection, industrial ventilation, and vehicle ventilation. A list of these candidates with selected performance and design specifications is shown in Table 2.

Table 2. Commercial Fan Candidates

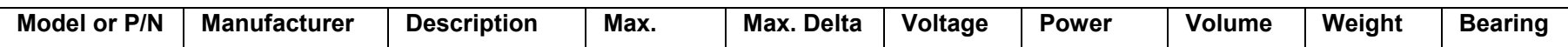




\begin{tabular}{|c|c|c|c|c|c|c|c|c|c|}
\hline & & & $\begin{array}{l}\text { Flow } \\
\text { (CFM) }\end{array}$ & $\begin{array}{l}\text { Pressure } \\
\text { (in. } \mathrm{H}_{2} \mathrm{O} \text { ) }\end{array}$ & & & (in^3) & (oz) & Type \\
\hline 119498 & Ametek & $\begin{array}{l}\text { 3.3" BLDC } \\
\text { Low-Voltage } \\
\text { Blower }\end{array}$ & 7.4 & 25 & 24 V DC & $\begin{array}{l}33 \mathrm{~W} \text { at } \\
4.7 \mathrm{CFM}\end{array}$ & 9.7 & 9.6 & $\begin{array}{l}\text { Ball } \\
\text { Bearing }\end{array}$ \\
\hline 119395 & Ametek & $\begin{array}{l}\text { 4.5" BLDC } \\
\text { Low-Voltage } \\
\text { Blower }\end{array}$ & 9.8 & 28 & 24 V DC & $\begin{array}{l}44 \mathrm{~W} \text { at } \\
4.7 \mathrm{CFM}\end{array}$ & 13.3 & 9.6 & $\begin{array}{l}\text { Ball } \\
\text { Bearing }\end{array}$ \\
\hline BFB1224GH & Delta & $\begin{array}{l}\text { BFB } 120 \times 120 \\
\text { x } 32 \mathrm{~mm} \\
\text { Series Blower }\end{array}$ & 60.4 & 4.1 & $24 \mathrm{~V} \mathrm{DC}$ & $\begin{array}{l}38.4 \mathrm{~W} \\
\text { input } \\
\text { power }\end{array}$ & 20.5 & 10.4 & $\begin{array}{l}\text { Ball } \\
\text { Bearing }\end{array}$ \\
\hline $\begin{array}{l}\text { U51DX- } \\
\text { 024KK-5 }\end{array}$ & Micronel & $\begin{array}{l}50 \times 32.5 \mathrm{~mm} \\
\text { Blower }\end{array}$ & 16.7 & 15.9 & 24 V DC & $\begin{array}{l}30.5 \mathrm{~W} \text { at } \\
\text { max flow }\end{array}$ & 4.3 & 3.17 & $\begin{array}{l}\text { Ball } \\
\text { Bearing }\end{array}$ \\
\hline $\begin{array}{l}\text { U97DR- } \\
\text { 024KK-4 }\end{array}$ & Micronel & $\begin{array}{l}\text { Miniature } \\
\text { Radial Blower }\end{array}$ & 27.2 & 7.2 & 24 V DC & $\begin{array}{l}19.2 \mathrm{~W} \text { at } \\
50 \% \text { max } \\
\text { flow }\end{array}$ & 14.6 & 6.69 & $\begin{array}{l}\text { Ball } \\
\text { Bearing }\end{array}$ \\
\hline $\begin{array}{l}\text { Rotron } \\
\text { Model R } \\
\text { Type } 201\end{array}$ & Ametek & Radial Blower & 12.5 & 11 & 24 V DC & $22 \mathrm{~W}$ & 16.6 & 23 & $\begin{array}{l}\text { Ball } \\
\text { Bearing }\end{array}$ \\
\hline U97 & Micronel & Radial Blower & 28 & 6 & 12 V DC & $\begin{array}{l}15 \mathrm{~W} \text { at } \\
4.7 \mathrm{CFM}\end{array}$ & 14.6 & 6.9 & $\begin{array}{l}\text { Ball } \\
\text { Bearing }\end{array}$ \\
\hline LENZ & Honeywell & $\begin{array}{l}\text { Miniature } \\
\text { Radial Blower }\end{array}$ & 15 & 8.5 & $\begin{array}{l}12 \text { or } 28 \\
V D C\end{array}$ & $\begin{array}{l}27 \mathrm{~W} \\
\text { input } \\
\text { power }\end{array}$ & 10.1 & 11.4 & unknown \\
\hline $\begin{array}{l}\text { U150R- } \\
\text { 024KK-4 }\end{array}$ & Micronel & $\begin{array}{l}\text { Miniature } \\
\text { Radial Blower }\end{array}$ & 40.6 & 13.5 & 24 V DC & $\begin{array}{l}49 \mathrm{~W} \text { at } \\
\text { working } \\
\text { point }\end{array}$ & 29.3 & 12 & $\begin{array}{l}\text { Ball } \\
\text { Bearing }\end{array}$ \\
\hline $\begin{array}{l}\text { Cathode } \\
\text { Blower } \\
\text { Prototype }\end{array}$ & R\&D Dynamics & $\begin{array}{l}\text { Gas Bearing } \\
\text { High-Speed } \\
\text { Centrifugal } \\
\text { Blower }\end{array}$ & 53 & 81 & unknown & $\begin{array}{l}>595 \mathrm{~W} \text { at } \\
\text { design } \\
\text { point }\end{array}$ & unknown & unknown & $\begin{array}{l}\text { Gas } \\
\text { Bearing }\end{array}$ \\
\hline $\mathrm{N} / \mathrm{A}$ & $\begin{array}{l}\text { Mohawk } \\
\text { Innovative } \\
\text { Technology }\end{array}$ & $\begin{array}{l}\text { Gas Bearing } \\
\text { Compressor } \\
\text { and Expander }\end{array}$ & unknown & unknown & unknown & unknown & unknown & unknown & $\begin{array}{l}\text { Gas } \\
\text { Bearing }\end{array}$ \\
\hline
\end{tabular}

\subsection{COMMERCIAL PUMPS}

The limited selection of commercial positive displacement pump candidates arises from the difficulty in finding pumps of a reasonable size that are capable of producing the required flow of $4.7 \mathrm{cfm}$. Many of the candidates produce flow well below the PLSS requirement, however the option of using two pumps in parallel, effectively adding their respective flow rates, was considered in order to increase the number of candidates. A list of the 9 commercial pump candidates is presented in Table 3.

Table 3. Commercial Pump Candidates

\begin{tabular}{|c|c|c|c|c|c|c|c|c|}
\hline Model or P/N & Manufacturer & Description & $\begin{array}{l}\text { Approx. Flow at } \\
6.3 \text { in. } \mathrm{H}_{2} \mathrm{O} \\
\text { (CFM) }\end{array}$ & $\begin{array}{l}\text { DC } \\
\text { Voltage }\end{array}$ & Power & $\begin{array}{l}\text { Volume } \\
(\text { in^3) }\end{array}$ & $\begin{array}{l}\text { Weight } \\
\text { (lbs) }\end{array}$ & Pump Type \\
\hline TA-5102E & Thomas & $\begin{array}{l}\text { 1/2 HP Articulating } \\
\text { Piston Compressor }\end{array}$ & 3.35 & 24 & 373 W max & 1166 & 40 & $\begin{array}{l}\text { Articulating } \\
\text { Piston }\end{array}$ \\
\hline T2-01 TH BLDC & $\begin{array}{l}\text { Parker } \\
\text { Hannifin }\end{array}$ & $\begin{array}{l}\text { Twin Head } \\
\text { Miniature }\end{array}$ & 2.3 & 24 & $72 \mathrm{~W}$ max & 78 & 3.1 & Diaphragm \\
\hline
\end{tabular}




\begin{tabular}{|c|c|c|c|c|c|c|c|c|}
\hline & & Diaphragm Pump & & & & & & \\
\hline 2907CDC22/12 & Thomas & $\begin{array}{l}\text { DC Diaphragm } \\
\text { Pump }\end{array}$ & 3.2 & 12 & $240 \mathrm{~W}$ & 479 & 11 & Diaphragm \\
\hline 118ZC20/24 & Thomas & $\begin{array}{l}\text { Double Diaphragm } \\
\text { Compressor }\end{array}$ & 1.9 & 24 & $\begin{array}{l}85 \mathrm{~W} \\
\text { at } 6.3 \mathrm{in} . \\
\mathrm{H}_{2} \mathrm{O}\end{array}$ & 139 & 4.4 & $\begin{array}{l}\text { Double } \\
\text { Diaphragm }\end{array}$ \\
\hline 6025SE & Thomas & $\begin{array}{l}\text { DC Linear } \\
\text { Diaphragm Pump }\end{array}$ & 1.7 & 24 & $36 \mathrm{~W}$ max & 78.76 & 3.3 & $\begin{array}{l}\text { Linear } \\
\text { Diaphragm }\end{array}$ \\
\hline SR-0030-BLDC & Thomas & $\begin{array}{l}\text { Brushless DC } \\
\text { Rotary Pump }\end{array}$ & 2.8 & 24 & $125 \mathrm{~W}$ & 52 & 4.75 & Rotary \\
\hline DTE 1024 DC & Thomas & Rotary Vane Pump & 5.9 & 24 & $420 \mathrm{~W} \max$ & 238 & 26 & Rotary Vane \\
\hline DTE 824 DC & Thomas & Rotary Vane Pump & 4.7 & 24 & $370 \mathrm{~W}$ max & 237 & 20.3 & Rotary Vane \\
\hline DTE 624 DC & Thomas & Rotary Vane Pump & 3.5 & 24 & $250 \mathrm{~W}$ max & 215 & 18.7 & Rotary Vane \\
\hline
\end{tabular}

\subsection{NASA FANS}

Five fans already in use by NASA on the Space Shuttle and International Space Station (ISS) were also considered. The Avionics Air Assembly and Carbon Dioxide Removal Assembly fans were included for their use of foil gas bearings in spite of having a much larger capacity than required. A list of these candidates and their specifications is shown in Table 4.

Table 4. NASA Fans

\begin{tabular}{|c|c|c|c|c|c|c|c|c|c|}
\hline Application & Manufacturer & Description & $\begin{array}{l}\text { Nominal Delta } \\
\text { Pressure } \\
\text { (in. } \mathrm{H}_{2} \mathrm{O} \text { ) }\end{array}$ & $\begin{array}{l}\text { Nominal } \\
\text { Flow Rate } \\
\text { (CFM) }\end{array}$ & Voltage & Power & $\begin{array}{l}\text { Volume } \\
\text { (in^3) }\end{array}$ & $\begin{array}{l}\text { Weight } \\
\text { (Ibs) }\end{array}$ & $\begin{array}{l}\text { Bearing } \\
\text { Type }\end{array}$ \\
\hline $\begin{array}{l}\text { ISS Avionics Air } \\
\text { Assembly Fan }\end{array}$ & $\begin{array}{l}\text { Hamilton } \\
\text { Standard }\end{array}$ & $\begin{array}{l}\text { Gas Bearing } \\
\text { Axial Fan [13] }\end{array}$ & 2 & 120 & $\begin{array}{l}120 \mathrm{~V} \\
\mathrm{DC}\end{array}$ & $\begin{array}{l}170 \mathrm{~W} \\
\max \end{array}$ & 1957 & 26.6 & $\begin{array}{l}\text { Gas } \\
\text { Bearing }\end{array}$ \\
\hline $\begin{array}{l}\text { ISS Intermodule } \\
\text { Ventilation Fan }\end{array}$ & $\begin{array}{l}\text { Hamilton } \\
\text { Standard }\end{array}$ & $\begin{array}{l}\text { Axial } \\
\text { Ventilation fan } \\
{[14]}\end{array}$ & 1 & 140 & $\begin{array}{l}120 \mathrm{~V} \\
\mathrm{DC}\end{array}$ & $55 \mathrm{~W}$ & 594 & 10.5 & unknown \\
\hline $\begin{array}{l}\text { Shuttle Inertial } \\
\text { Measurement } \\
\text { Unit (IMU) Fan }\end{array}$ & $\begin{array}{l}\text { Hamilton } \\
\text { Sundstrand }\end{array}$ & $\begin{array}{l}\text { Centrifugal } \\
\text { cooling fans } \\
{[14]}\end{array}$ & 4.5 & 32 & $\begin{array}{l}115 \mathrm{~V} \\
\mathrm{AC}\end{array}$ & $50 \mathrm{~W}$ & 294 & 4.7 & unknown \\
\hline $\begin{array}{l}\text { Shuttle Crew- } \\
\text { Cabin Air Fan }\end{array}$ & unknown & $\begin{array}{l}\text { Axial } \\
\text { Ventilation fan } \\
{[14]}\end{array}$ & 6.7 & 352 & $\begin{array}{l}115 \mathrm{~V} \\
A C\end{array}$ & $495 \mathrm{~W}$ & 344 & 5.95 & unknown \\
\hline $\begin{array}{l}\text { ISS Carbon } \\
\text { Dioxide Removal } \\
\text { Assembly Blower }\end{array}$ & Allied Signal & $\begin{array}{l}\text { Mixed-flow, } \\
\text { gas bearing } \\
\text { blower [15] }\end{array}$ & 23 & 25.5 & $\begin{array}{l}120 \mathrm{~V} \\
\mathrm{DC}\end{array}$ & $170 \mathrm{~W}$ & 45.3 & 12.3 & $\begin{array}{l}\text { Gas } \\
\text { Bearing }\end{array}$ \\
\hline
\end{tabular}




\section{SCALING AND ANALYSIS}

For this study, it was necessary to scale the performance of the candidates to the flow requirements of $4.7 \mathrm{cfm}$ and 6.3 in. $\mathrm{H}_{2} \mathrm{O}$ delta pressure at 14.7 psia atmospheric pressure. None of the fans or pumps perfectly met the requirement, but it was possible to predict what changes in motor speed and power were required to meet the performance goals. The PLSS impact of each fan and pump's power draw in the form of added battery and cooling water mass was also predicted. These techniques allowed all the candidates to be assessed on an equal performance basis.

\subsection{PERFORMANCE SCALING}

\subsubsection{FAN PERFORMANCE SCALING}

The performance curve for most fan candidates, showing the relationship between volumetric flow and delta pressure at a constant voltage, was given by the manufacturers or in technical papers. The Fan Laws were used to scale each performance curve to intersect the flow and pressure requirement. Since most candidates were commercially produced, with a set impeller size, scaling was performed based on fan speed alone. The Fan Laws allow for volumetric flow, delta pressure, and fan power to be scaled based on changes in fan speed using equations 1,2 , and 3 .

$$
\begin{aligned}
& \mathbf{C F M}_{2}=\mathbf{C F M}_{1}\left(\frac{\mathbf{R P M}_{2}}{\mathbf{R P M}_{1}}\right)^{1} \\
& \Delta \mathbf{P}_{2}=\Delta \mathbf{P}_{1}\left(\frac{\mathbf{R P M}_{2}}{\mathbf{R P M}_{1}}\right)^{2} \\
& \text { Power }_{2}=\text { Power }_{1}\left(\frac{\mathbf{R P M}_{2}}{\mathbf{R P M}_{1}}\right)^{3}
\end{aligned}
$$

To apply these relationships to the fan performance curves, each curve was reproduced in Excel by selecting and graphing multiple points along each original performance curve. In the same graphs, a separate point marked the performance goal of 6.3 in. $\mathrm{H}_{2} \mathrm{O}$ and $4.7 \mathrm{cfm}$ or 9.5 in. $\mathrm{H}_{2} \mathrm{O}$ and $5.9 \mathrm{cfm}$. The spreadsheets were programmed to apply the scaling laws to each point on the performance curve based on a selected RPM ratio. The RPM ratio was varied until the scaled performance curve intersected the flow requirement. The input power was scaled based on this RPM ratio. A general example of this visual scaling method is shown in Figure 9. Appendix A contains the $4.7 \mathrm{cfm}$ case scaled performance curves for each fan candidate. 


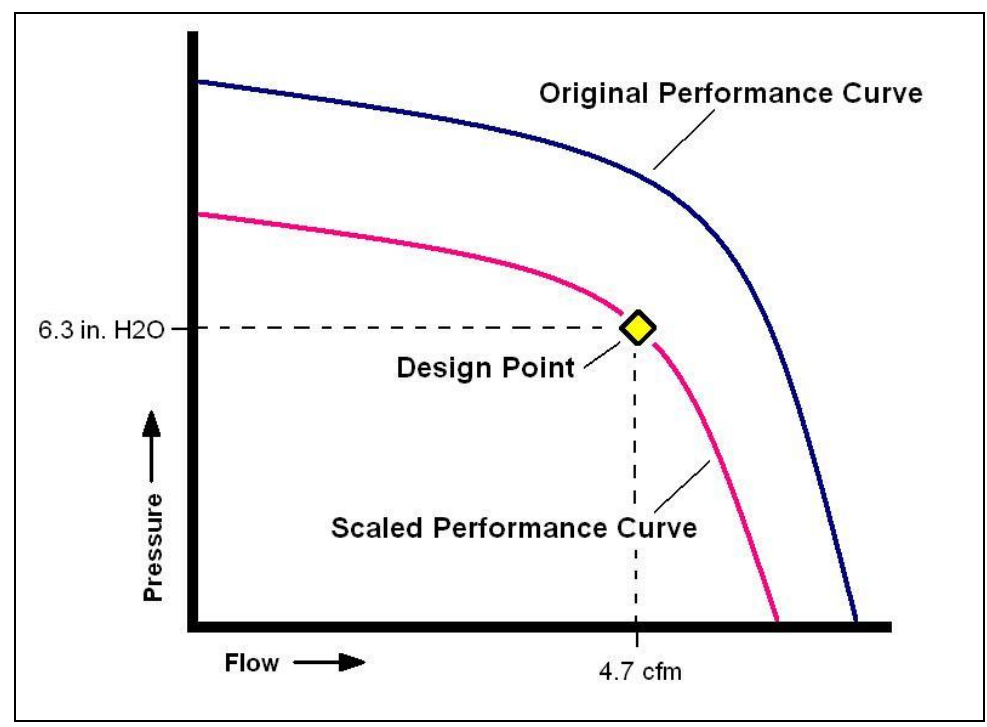

Figure 9. Visual Performance Scaling Technique

Two exceptions to this performance scaling method should be noted. First, the performance curve of the current EMU fan was measured at an absolute pressure of 3.73 psi. The visual scaling method used was the same as described previously, however the design point of 6.3 in. $\mathrm{H}_{2} \mathrm{O}$ and $4.7 \mathrm{cfm}$ at 14.7 psia was converted to its equivalent at 3.73 psia using the same technique described in Section 3.1.

The second exception would be the scaling performed on the prototype gas bearing EMU fan performance. The performance curves for this fan were not derived in the manner described in Section 2.1.2. Instead, the hydraulic impedance was kept constant while the fan's speed was increased. This was performed at various absolute pressures, ranging from 6 psi to 23 psi. Figure 10 shows the prototype EMU fan performance curves.

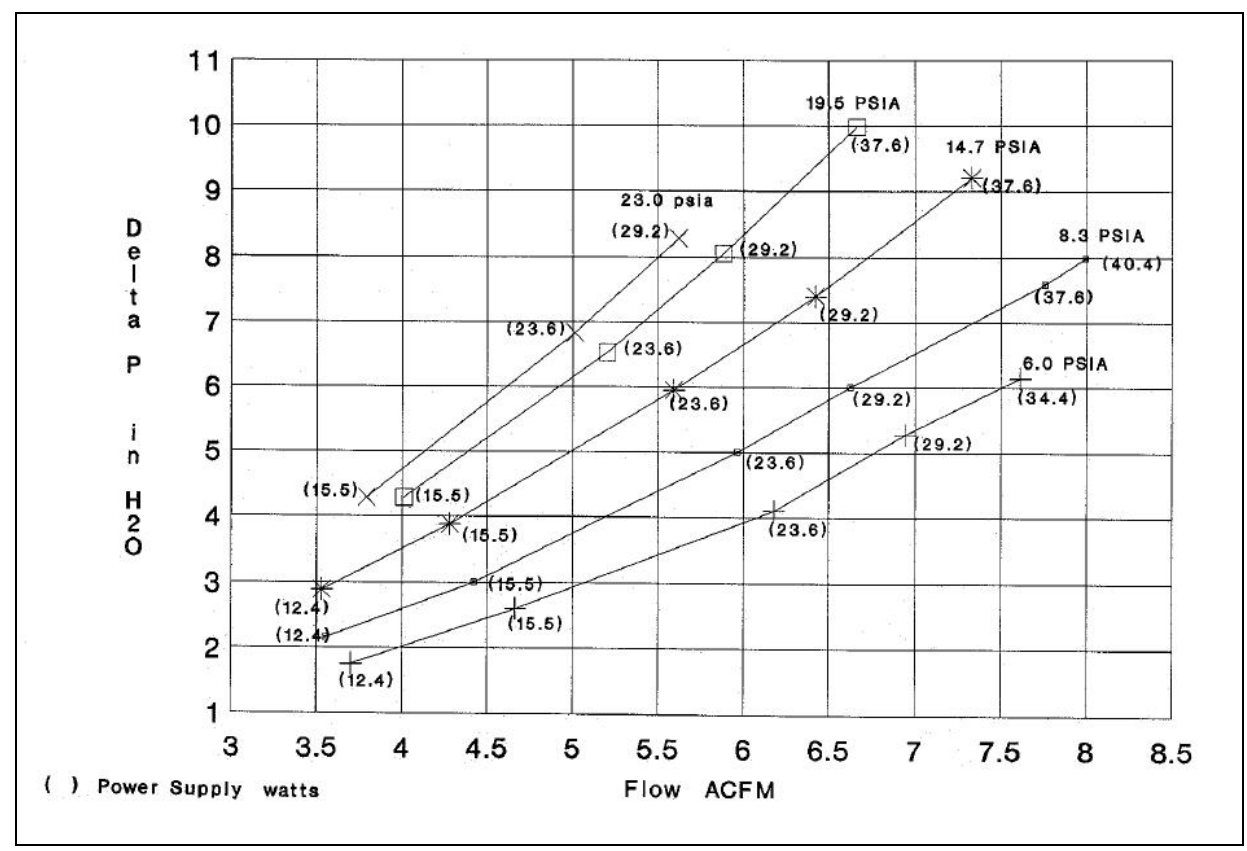

Figure 10. Prototype Gas Bearing EMU Fan Performance Curves [11]

To estimate the prototype EMU fan performance at an absolute pressure of $4.3 \mathrm{psi}$, fan delta pressures and input power values were interpolated using test data in Figure 10 and then plotted with respect to absolute atmospheric pressure. The required fan power was estimated assuming a 
linear function between the bounding power data points. These results are plotted in Figure 11 as well as curve fits extrapolated to 4 psia.

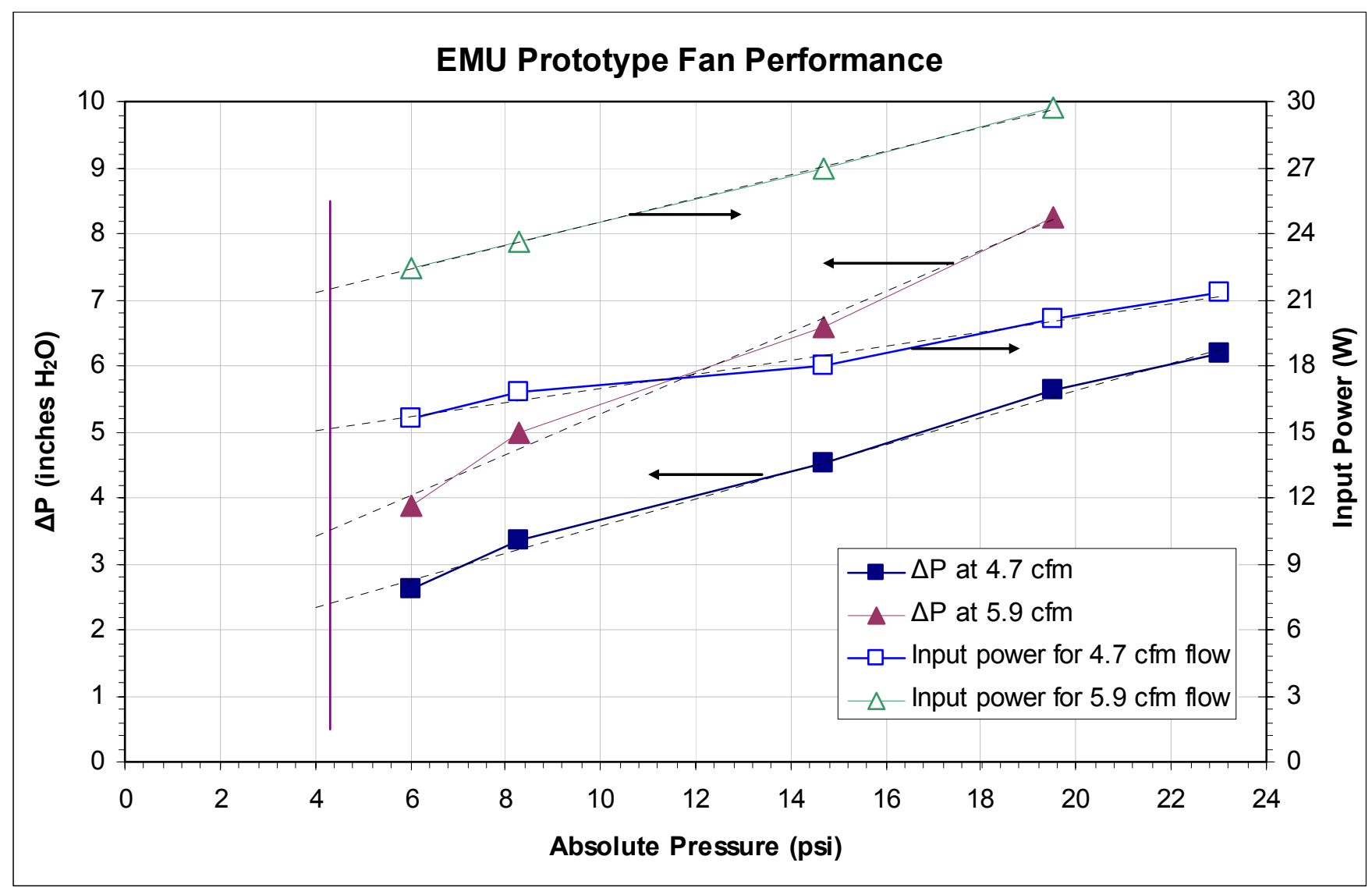

Figure 11. Prototype Gas Bearing EMU Fan Performance Estimation at 4.3 psia Atmospheric Pressure and Fan Inlet Flow Rates of 4.7 and $5.9 \mathrm{cfm}$

From this graph it can be seen that at 4.3 psia the EMU prototype fan will produce a 2.4 in. $\mathrm{H}_{2} \mathrm{O}$ delta pressure at $4.7 \mathrm{cfm}$, with an input power of about $16 \mathrm{~W}$. The performance goal of a $2.2 \mathrm{in}$. $\mathrm{H}_{2} \mathrm{O}$ delta pressure at $4.7 \mathrm{cfm}$ is $92 \%$ of the predicted performance. Equation 2 suggests that the fan requires an $96 \%$ scaling of the fan speed to reach the desired 2.2 in. $\mathrm{H}_{2} \mathrm{O}$ delta pressure. Using the fan laws would also show that an $96 \%$ fan speed scaling would result in a drop in flow rate from $4.7 \mathrm{cfm}$ to $4.5 \mathrm{cfm}$. This shows that the scaling should be higher to ensure the $4.7 \mathrm{cfm}$ flow requirement is met. In lieu of iterating upon the proper scaling without a 4.3 psia fan performance curve, the scaling is assumed to be $95 \%$. If the previous assumption is made that the input power is a linear function of fan speed, a 95\% fan speed scaling would decrease required input power from $15 \mathrm{~W}$ to $14 \mathrm{~W}$. A similar exercise for the $5.9 \mathrm{cfm}$ case results in an assumed fan speed scaling of $99 \%$ and a required input power of $21.6 \mathrm{~W}$.

\subsubsection{POSITIVE DISPLACEMENT PUMP PERFORMANCE SCALING}

Relationships similar to the Fan Laws exist between positive displacement pump speed, flow rate, and power. Pump performance was scaled using equations 4 and 5 . It was sometimes preferable to consider using two pumps in parallel rather than scaling the performance of a single pump. For 
the purposes of this study, the configuration that required the least amount of scaling was selected. Appendix B contains the scaled performance of each pump candidate.

$$
\begin{aligned}
& \mathrm{CFM}_{2}=\mathrm{CFM}_{1}\left(\frac{\mathrm{RPM}_{2}}{\mathrm{RPM}_{1}}\right) \\
& \text { Power }_{2}=\text { Power }_{1}\left(\frac{\mathrm{RPM}_{2}}{\mathrm{RPM}_{1}}\right)
\end{aligned}
$$

\subsection{PLSS IMPACTS}

Consideration was given to the added battery and cooling water mass resulting from each candidate's power consumption to accurately assess the impact of each candidate on the total PLSS mass. Using the scaled power of each device, the battery mass required to power each device for an 8 hour EVA and the cooling water mass required to remove the produced heat was calculated and added to the weight of each device, giving a total mass for each candidate. For this study, the operational time of the PLSS was assumed to be 8 hours. The battery was assumed to provide 40.8 watt-hours $(\mathrm{Wh})$ of energy per pound mass $(\mathrm{lbm})$ of battery while the cooling water was assumed to remove $305 \mathrm{Wh}$ of heat energy per pound mass of cooling water evaporated.

\subsection{CANDIDATE SCALING AND IMPACT SUMMARY}

Table 5 contains a summary of the performance scaling and total mass results for each device. The "Required RPM Scaling" is given in terms of the ratio of original fan speed to the speed required to produce 6.3 in. $\mathrm{H}_{2} \mathrm{O}$ at $4.7 \mathrm{cfm}$. Ratios below 1 indicate a decrease in device speed, while ratios above 1 indicate an increase in device speed.

Four of the NASA designed fans, the Avionics Air Assembly, Intermodule Ventilation, Inertial Measurement Unit, and Crew Cabin Air fans, are not included in the summary and will no longer be discussed in this report. It was found through inspection that their performance was an extremely poor fit for the PLSS application. Although they are designed for ventilation, their flow capacity is several times greater, and pressure capacity several times less, than the PLSS requirements. Without major design modifications their performance in the PLSS ventilation subsystem would be highly inefficient.

Additionally, R\&D Dynamics and Mohawk Innovative Technology gas bearing fans are not included in the summary, nor will they be included in the remainder of this report. They are examples of the application of foil gas bearing technology to smaller scale centrifugal fans, and because of their early stages of development, lack the performance data needed for proper scaling and comparisons.

Table 5. Performance Scaling and Corrected Total Mass Data

\begin{tabular}{|l|l|l|l|l|l|}
\hline Model & $\begin{array}{l}\text { Required RPM } \\
\text { Scaling }\end{array}$ & Scaled Power (W) & $\begin{array}{l}\Delta \text { Battery Mass } \\
\text { (lbs) }\end{array}$ & $\begin{array}{l}\Delta \text { Water Mass } \\
\text { (lbs) }\end{array}$ & $\begin{array}{l}\text { Total Mass } \\
\text { (lbs) }\end{array}$ \\
\hline Ametek 119350 & 0.85 & 10 & 1.87 & 0.25 & 2.72 \\
\hline Ametek 119383 & 0.69 & 11 & 2.19 & 0.29 & 3.68 \\
\hline Ametek 119498 & 0.8 & 17 & 3.31 & 0.44 & 4.36 \\
\hline Ametek 119395 & 0.71 & 16 & 3.09 & 0.41 & 4.1 \\
\hline Delta BFB1224GH & 1.27 & 81 & 15.79 & 2.11 & \\
\hline Micronel U51DX-024KK-5 & 0.69 & 10 & 1.96 & 0.26 & 2.43 \\
\hline Micronel U51D2-024KK-5 & 0.5 & 9 & 1.71 & 0.23 & 2.49 \\
\hline
\end{tabular}




\begin{tabular}{|c|c|c|c|c|c|}
\hline Micronel U51D1-024KK-5 & 0.88 & 10 & 1.88 & 0.25 & 2.55 \\
\hline Micronel U97DR-024KK-4 & 0.98 & 18 & 3.54 & 0.47 & 4.44 \\
\hline $\begin{array}{l}\text { Ametek Rotron Model R Type } \\
201\end{array}$ & 0.91 & 18 & 3.55 & 0.47 & 5.46 \\
\hline Micronel U97 & 1.06 & 18 & 3.5 & 0.47 & 4.4 \\
\hline Honeywell LENZ & 0.9 & 20 & 3.86 & 0.52 & 5.09 \\
\hline Micronel U150R-024KK-4 & 0.7 & 18 & 3.44 & 0.46 & 4.65 \\
\hline Micronel U51DL & 0.74 & 13 & 2.53 & 0.34 & 3.07 \\
\hline Thomas TA-5102E & 1.4 & 523 & 102.61 & 13.73 & 156.34 \\
\hline Parker Hannifin T2-01 TH BLDC & $\begin{array}{l}1.02 \text { (two pump } \\
\text { configuration) }\end{array}$ & 147 & 28.85 & 3.86 & 38.91 \\
\hline Thomas 2907CDC22/12 & 1.47 & 353 & 69.12 & 9.25 & 89.36 \\
\hline Thomas 118ZC20/24 & $\begin{array}{l}1.24 \text { (two pump } \\
\text { configuration) }\end{array}$ & 210 & 41.23 & 5.52 & 55.54 \\
\hline Thomas 6025SE & $\begin{array}{l}1.38 \text { (two pump } \\
\text { configuration) }\end{array}$ & 100 & 19.52 & 2.61 & 28.73 \\
\hline Thomas SR-0030-BLDC & $\begin{array}{l}0.84 \text { (two pump } \\
\text { configuration) }\end{array}$ & 210 & 41.14 & 5.5 & 56.14 \\
\hline Thomas DTE 1024 DC & 0.8 & 335 & 65.6 & 8.78 & 100.38 \\
\hline Thomas DTE 824 DC & 1 & 370 & 72.55 & 9.7 & 102.55 \\
\hline Thomas DTE 624 DC & 1.34 & 336 & 65.83 & 8.81 & 93.33 \\
\hline $\begin{array}{l}\text { ISS Carbon Dioxide Removal } \\
\text { System Blower }\end{array}$ & 0.37 & 9 & 1.2 & 0.16 & 13.66 \\
\hline Current EMU Fan & 0.69 & 11 & 2.25 & 0.3 & 6.06 \\
\hline Prototype Gas Bearing EMU Fan & Less than .88 & 14 & 2.75 & 0.37 & 5.11 \\
\hline
\end{tabular}

\section{CANDIDATE COMPARISON}

\subsection{RATING SYSTEM}

A rating system based on fan speed (revolutions per minute, RPM) scaling, mass, volume, and power was developed for the purpose of comparing and ranking each device. For each device, a rating from 1 to 5 was given in each category based on the criteria listed in Table 6.

Table 6. Rating System Criteria

\begin{tabular}{|l|c|c|c|c|c|}
\hline Parameter & $\mathbf{5}$ & $\mathbf{4}$ & $\mathbf{3}$ & $\mathbf{2}$ & $\mathbf{1}$ \\
\hline RPM Scaling (\%) & $90-105$ & $80-89$ or $106-110$ & $70-79$ or $111-115$ & $60-69$ or $116-120$ & $<60$ or $>120$ \\
\hline Total Mass (lbs) & $<4$ & $4-8$ & $9-12$ & $13-16$ & $>17$ \\
\hline Volume $\left(\right.$ in $\left.^{3}\right)$ & $<10$ & $10-20$ & $21-30$ & $31-40$ & $>41$ \\
\hline Power $(\mathrm{W})$ & $\leq 10$ & $11-20$ & $21-30$ & $31-40$ & $>41$ \\
\hline
\end{tabular}

The rationale for including RPM scaling as a criterion in the rating system is two-fold. First, RPM scaling can be seen as a measurement of how close the devices original performance comes to meeting the PLSS design goals. It is assumed that a device will operate most efficiently at the speed it was designed for and tested at. Second, the Fan Laws and pump relationships are known to be accurate for small changes in performance, but it is unclear how well they hold for large changes in performance. It is assumed that the fan and pump scaling relationships give less accurate predictions of performance as the amount of scaling increases.

\subsection{RANKING RESULTS}

The scores in each of the four categories were added for each candidate to give their total scores. Tables 7 and 8 list the candidates in order from highest to lowest total score for the 4.7 and 5.9 cfm flow rates, respectively. The rows are colored to denote the type of device; red representing 
commercial fans, blue representing commercial pumps, and yellow representing baselines and NASA fans.

Several trends are immediately apparent upon a cursory look at the $4.7 \mathrm{cfm}$ case results in Table 7. First, the positive displacement pumps occupied almost all bottom rankings due to their significant disadvantages in almost every category. Pump total scores ranged from 4 to 8 . Meanwhile, commercial centrifugal fans and the EMU prototype fan occupied the top six rankings with total scores ranging from 17 to 19. A collection of commercial fans and NASA fans occupied the middle rankings with scores ranging from 9 to 16 . The same trends are noted in the $5.9 \mathrm{cfm}$ case results even though the scores defining the middle and top rankings differ slightly from the $4.7 \mathrm{cfm}$ results.

The top candidates for both flow rate cases were the same six fans consisting of two types of centrifugal fans and the EMU prototype gas bearing axial fan. The U51 series fans are classified by Micronel as miniature radial blowers while the other commercial fans appear to be traditional centrifugal fans, probably using backward curved fan blades. For reference, the Space Shuttle EMU fan uses this latter centrifugal design.

Several interesting design features stand out when comparing the Micronel U51 series fans to the other top performing commercial centrifugal fans. First, the U51 series fan blades appear to be a cross between backwards curved and radial blades (see Appendix A). Second, the U51 series fans housing does not conform closely to the blades as in an open radial design. The housings of the other commercial fans, however, tightly enclose the fan blades as would be expected of typical centrifugal, backwards impeller designs. Finally, the U51 series fans operate at speeds ranging from 29,000 to $39,000 \mathrm{rpm}$ whereas the other centrifugal fans operate at speeds ranging from 15,000 to $25,200 \mathrm{rpm}$. The gas bearing axial fan, in contrast, operates at fan speeds greater than $100,000 \mathrm{rpm}$.

Comparison of the 4.7 and $5.9 \mathrm{cfm}$ results illustrates that the $5.9 \mathrm{cfm}$ flow requirements demand more fan input power. Note, at 4.7 and $5.9 \mathrm{cfm}$, the 14.7 psia atmospheric pressure flow requirements of 6.3 and 9.5 in. $\mathrm{H}_{2} \mathrm{O}$ delta pressure yield required aerodynamic power of 3.5 and 6.6 W, respectively. All six top candidates needed 11-20 W of input power to meet the $4.7 \mathrm{cfm}$ delta pressure requirement of 2.2 in. $\mathrm{H}_{2} \mathrm{O}$, thus garnering a power rating of 4 . In comparison, the Micronel U51DL and EMU prototype gas bearing axial fan needed 21-30 W of input power whereas the Ametek 119498 required $33 \mathrm{~W}$ of power to meet the $5.9 \mathrm{cfm}$ flow requirements. Hence, their input power ratings ranged from 2 to 3.

One caveat exists regarding the input power of the Micronel U51 series fans. While it is known that the Micronel U51 series fans require an external driver to power the fan motor, it is not known if the reported fan electrical power consumption includes driver losses. The EMU prototype fan power dissipation does include driver electrical power losses, which could be as much as $7.2 \mathrm{~W}$. The Ametek and Micronel U97 series fans have an internal motor driver with reported fan electrical power consumptions believed to include driver losses. Consequently, comparisons of input power between the Micronel U51 series and the other top candidates might not have the same basis.

Table 7. Candidate Rankings Based on Total Score for $4.7 \mathrm{cfm}$ Inlet Volumetric Flow Rate 


\begin{tabular}{|c|c|c|c|c|c|c|c|}
\hline Manufacturer & Model or P/N & Description & RPM Scaling & Total Mass & Volume & Power & Total \\
\hline Micronel & U51D1-024KK-5 & Miniature Radial Blower & 5 & 5 & 5 & 4 & 19 \\
\hline Ametek & 119350 & $\begin{array}{l}\text { 3.0" BLDC Low-Voltage } \\
\text { Blower }\end{array}$ & 5 & 5 & 4 & 4 & 18 \\
\hline Allied-Signal & \begin{tabular}{|l} 
EMU Prototype Air \\
Bearing Fan
\end{tabular} & $\begin{array}{l}\text { High-Speed Axial Air } \\
\text { Bearing Fan } \\
\end{array}$ & 5 & 4 & 4 & 4 & 17 \\
\hline Ametek & 119498 & $\begin{array}{l}\text { 3.3" BLDC Low-Voltage } \\
\text { Blower }\end{array}$ & 4 & 4 & 5 & 4 & 17 \\
\hline Micronel & U51DX-024KK-5 & $50 \times 32.5 \mathrm{~mm}$ Blower & 3 & 5 & 5 & 4 & 17 \\
\hline Micronel & U51DL & Miniature Radial Blower & 3 & 5 & 5 & 4 & 17 \\
\hline Micronel & U97DR-024KK-4 & Miniature Radial Blower & 5 & 4 & 4 & 3 & 16 \\
\hline Honeywell & LENZ & Miniature Radial Blower & 5 & 4 & 4 & 3 & 16 \\
\hline Ametek & $\begin{array}{l}\text { Rotron Model R Type } \\
201\end{array}$ & Radial Blower & 5 & 4 & 4 & 3 & 16 \\
\hline Ametek & 119395 & $\begin{array}{l}\text { 4.5" BLDC Low-Voltage } \\
\text { Blower }\end{array}$ & 3 & 4 & 4 & 4 & 15 \\
\hline Micronel & U51D2-024KK-5 & Miniature Radial Blower & 1 & 5 & 4 & 5 & 15 \\
\hline Micronel & U97 & Radial Blower & 3 & 4 & 4 & 3 & 14 \\
\hline Micronel & U150R & Miniature Radial Blower & 3 & 4 & 3 & 3 & 13 \\
\hline Ametek & 119383 & $\begin{array}{l}\text { 5.0" BLDC Low-Voltage } \\
\text { Blower }\end{array}$ & 3 & 4 & 1 & 4 & 12 \\
\hline NASA & Current EMU Fan & Centrifugal Ventilation Fan & 3 & 4 & 1 & 4 & 12 \\
\hline NASA & $\begin{array}{l}\text { Carbon Dioxide Removal } \\
\text { System Blower }\end{array}$ & $\begin{array}{l}\text { Mixed-flow, air bearing } \\
\text { blower }\end{array}$ & 1 & 2 & 1 & 5 & 9 \\
\hline Parker Hannifin & T2-01 TH BLDC & $\begin{array}{l}\text { Twin Head Miniature } \\
\text { Diaphragm Pump } \\
\end{array}$ & 5 & 1 & 1 & 1 & 8 \\
\hline Thomas & DTE 824 DC & Rotary Vane Pump & 5 & 1 & 1 & 1 & 8 \\
\hline Thomas & SR-0030-BLDC & $\begin{array}{l}\text { Brushless DC Rotary } \\
\text { Pump }\end{array}$ & 4 & 1 & 1 & 1 & 7 \\
\hline Thomas & DTE 1024 DC & Rotary Vane Pump & 3 & 1 & 1 & 1 & 6 \\
\hline Delta & BFB1224GH & $\begin{array}{l}\text { BFB 120 x } 120 \times 32 \mathrm{~mm} \\
\text { Series Blower }\end{array}$ & 1 & 1 & 3 & 1 & 6 \\
\hline Thomas & 118ZC20/24 & \begin{tabular}{|l|} 
Double Diaphragm \\
Compressor
\end{tabular} & 1 & 1 & 1 & 1 & 4 \\
\hline Thomas & DTE 624 DC & Rotary Vane Pump & 1 & 1 & 1 & 1 & 4 \\
\hline Thomas & $6025 S E$ & $\begin{array}{l}\text { DC Linear Diaphragm } \\
\text { Pump }\end{array}$ & 1 & 1 & 1 & 1 & 4 \\
\hline Thomas & TA-5102E & $\begin{array}{l}\text { 1/2 HP Articulating Piston } \\
\text { Compressor }\end{array}$ & 1 & 1 & 1 & 1 & 4 \\
\hline Thomas & 2907CDC22/12 & DC Diaphragm Pump & 1 & 1 & 1 & 1 & 4 \\
\hline
\end{tabular}


Table 8 Candidate Rankings Based on Total Score for $5.9 \mathrm{cfm}$ Inlet Volumetric Flow Rate

\begin{tabular}{|c|c|c|c|c|c|c|c|}
\hline Manufacturer & Model or P/N & Description & RPM Scaling & Total Mass & Volume & Power & Total \\
\hline Micronel & U51DL & Miniature Radial Blower & 5 & 5 & 5 & 3 & 18 \\
\hline \begin{tabular}{|l} 
Micronel \\
\end{tabular} & U51D1-024KK-5 & Miniature Radial Blower & 4 & 5 & 5 & 4 & 18 \\
\hline Micronel & U51DX-024KK-5 & $50 \times 32.5 \mathrm{~mm}$ Blower & 4 & 5 & 5 & 4 & 18 \\
\hline Ametek & 119350 & $\begin{array}{l}\text { 3.0" BLDC Low-Voltage } \\
\text { Blower }\end{array}$ & 4 & 5 & 4 & 4 & 17 \\
\hline Ametek & 119498 & $\begin{array}{l}\text { 3.3" BLDC Low-Voltage } \\
\text { Blower }\end{array}$ & 5 & 4 & 5 & 2 & 16 \\
\hline Allied-Signal & $\begin{array}{l}\text { EMU Prototype Air } \\
\text { Bearing Fan }\end{array}$ & $\begin{array}{l}\text { High-Speed Axial Air } \\
\text { Bearing Fan }\end{array}$ & 5 & 4 & 4 & 3 & 16 \\
\hline Ametek & 119395 & $\begin{array}{l}\text { 4.5" BLDC Low-Voltage } \\
\text { Blower }\end{array}$ & 4 & 4 & 4 & 3 & 15 \\
\hline Micronel & U51D2-024KK-5 & Miniature Radial Blower & 2 & 5 & 4 & 4 & 15 \\
\hline Honeywell & LENZ & Miniature Radial Blower & 4 & 4 & 4 & 2 & 14 \\
\hline Ametek & $\begin{array}{l}\text { Rotron Model R Type } \\
201\end{array}$ & Radial Blower & 4 & 4 & 4 & 2 & 14 \\
\hline NASA & Current EMU Fan & Centrifugal Ventilation Fan & 5 & 4 & 1 & 3 & 13 \\
\hline Micronel & U150R & Miniature Radial Blower & 4 & 4 & 3 & 2 & 13 \\
\hline Ametek & 119383 & $\begin{array}{l}\text { 5.0" BLDC Low-Voltage } \\
\text { Blower }\end{array}$ & 4 & 4 & 1 & 3 & 12 \\
\hline Micronel & U97DR-024KK-4 & Miniature Radial Blower & 1 & 4 & 4 & 2 & 11 \\
\hline Micronel & U97 & Radial Blower & 1 & 4 & 4 & 2 & 11 \\
\hline NASA & $\begin{array}{l}\text { Carbon Dioxide Removal } \\
\text { System Blower }\end{array}$ & $\begin{array}{l}\text { Mixed-flow, air bearing } \\
\text { blower }\end{array}$ & 1 & 2 & 1 & 5 & 9 \\
\hline Parker Hannifin & T2-01 TH BLDC & $\begin{array}{l}\text { Twin Head Miniature } \\
\text { Diaphragm Pump }\end{array}$ & 5 & 1 & 1 & 1 & 8 \\
\hline Thomas & DTE 824 DC & Rotary Vane Pump & 5 & 1 & 1 & 1 & 8 \\
\hline Thomas & SR-0030-BLDC & Brushless DC Rotary Pump & 4 & 1 & 1 & 1 & 7 \\
\hline Thomas & DTE 1024 DC & Rotary Vane Pump & 3 & 1 & 1 & 1 & 6 \\
\hline Delta & BFB1224GH & $\begin{array}{l}\text { BFB } 120 \times 120 \times 32 \mathrm{~mm} \\
\text { Series Blower }\end{array}$ & 1 & 1 & 3 & 1 & 6 \\
\hline Thomas & 118ZC20/24 & $\begin{array}{l}\text { Double Diaphragm } \\
\text { Compressor }\end{array}$ & 1 & 1 & 1 & 1 & 4 \\
\hline Thomas & DTE 624 DC & Rotary Vane Pump & 1 & 1 & 1 & 1 & 4 \\
\hline Thomas & $6025 S E$ & $\begin{array}{l}\text { DC Linear Diaphragm } \\
\text { Pump }\end{array}$ & 1 & 1 & 1 & 1 & 4 \\
\hline Thomas & TA-5102E & $\begin{array}{l}\text { 1/2 HP Articulating Piston } \\
\text { Compressor }\end{array}$ & 1 & 1 & 1 & 1 & 4 \\
\hline Thomas & 2907CDC22/12 & DC Diaphragm Pump & 1 & 1 & 1 & 1 & 4 \\
\hline
\end{tabular}

\section{CONCLUSIONS AND RECOMMENDATIONS}

An extensive survey of gas transport devices was performed to gain an understanding of the state of art technology for application in the CSSE PLSS ventilation loop. Many markets and technologies were investigated to find and then rank potential CSSE PLSS ventilation loop gas transport device candidates. Ranking results show that miniature radial centrifugal, traditional centrifugal, and gas bearing axial fans have the greatest potential to meet the 4.3 psia atmospheric pressure CSSE PLSS ventilation loop nominal and high flow requirements. Nominal gas transport device flow requirements were $4.7 \mathrm{cfm}$ and 2.2 inches $\mathrm{H}_{2} \mathrm{O}$ delta pressure while high flow requirements were $5.9 \mathrm{cfm}$ and 3.3 inches $\mathrm{H}_{2} \mathrm{O}$ delta pressure. One technology considered, positive displacement pumps, was shown to be least applicable to the CSSE PLSS due to their large power consumption, volumes, and masses. 
Three recommendations arise from this study. First, further analysis of the top three candidate technologies should be performed accounting for oxygen compatibility, shock load capabilities, durability, and potential failure modes. It is believed that oxygen compatibility will have the most significant impact on fan design and, thus, should be completely understood. Of the top ranking commercial fans, none are rated for oxygen systems whereas the ISS EMU prototype gas bearing axial fan incorporated some oxygen compatible features into its design. Second, state of the art brushless direct current (BLDC) motor driver technology should be investigated to understand how driver electrical losses can be minimized. All candidate fan technologies use BLDC motors. The ISS EMU prototype BLDC motor driver accounted for $25 \%$ of the total fan power consumption at the design point. It obviously would be a good idea to determine if current driver technology dissipates less power. Finally, some of the top ranking commercial fans should be purchased and should be evaluated in the PLSS ventilation loop testbed. The Micronel U51 series are especially appealing because they require an external driver. Consequently, more measurements can be performed to determine where the electrical power is consumed leading to a better understanding of the fan efficiencies. At least one traditional centrifugal fan should be purchased so that a comparison can be made between the miniature radial and traditional centrifugal fans.

1) Emmerling, R. Final Report- Development of an Air-Bearing Ventilation Fan for the Preprototype Subsystems for the Advanced EMU PLSS for Lockheed Engineering and Sciences Company. Allied-Signal Aerospace Company. 1992.

2) Perry, Robert H. Chemical Engineers' Handbook. 5th ed. New York: McGraw-Hill Book Company, 1973.

3) Turner, Mike. "All You Need to Know About Fans." Electronics Cooling (1996). <http://electronics-cooling.com/articles/1996/may/may96_01.php>.

4) "Fan Types." 1 Mar. 2006. U.S. Environmental Protection Agency. 17 Dec. 2007 <http://www.epa.gov/eogapti1/module5/fans/types/types.htm>.

5) "Pump Classifications Technical Notes." Kurt J. Lesker Company. 17 Dec. 2007 <http://www.lesker.com/newweb/Vacuum_Pumps/vacuumpumps_technicalnotes_1.cfm>.

6) Agrawal, Giri L. Foil Air/Gas Bearing Technology - An Overview. International Gas Turbine \& Aeroengine Congress \& Exhibition, 2-5 June 1997, American Society of Mechanical Engineers. New York: ASME, 1997.

7) Valco, Mark J., and Christopher Dellacorte. Emerging Oil-Free Turbomachinery Technology for Military Propulsion and Power Applications.

8) "Oil-Free Turbomachinery Program." 19 Feb. 2004. NASA Glenn Research Center. 17 Dec. 2007 <http://www.grc.nasa.gov/WWW/Oilfree/index.htm>.

9) Dellacorte, Christopher, and Mark J. Valco. Load Capacity Estimation of Foil Air Journal Bearings for Oil-Free Turbomachinery Applications. International Joint Tribology Conference, 1 Oct. 2000, Society of Tribologists and Lubrication Engineers. NASA, 2000.

10) "Constellation Space Suit Element Requirements Document Baseline (Draft)", CxP 72208, NASA-Johnson Space Center, 2008.

11) Certification Status Report, 1EVA-15-019, Rev.-. NASA. Hamilton Sundstrand, 2006.

12) Murry, Roger P. "An Air Bearing Fan for EVA Suit Ventilation." SAE Paper 901432 (1990).

13) O'connor, E, R Nason, D Rubalcaba, and J Klym. "Space Station Distributed Avionics Air Cooling." SAE Paper 941493 (1994).

14) Duffield, B E., M R. Kesterson, A T. Perka, and J P. Van Buskirk. Fixed-Bed Regenerative Carbon Dioxide Sorption Process, ESCG-4007-05-TEAN-DOC-0086. Jacobs ESCG. 2005.

15) Report No. 2K-70836, Revision 2. Honeywell. 